\section{Apparatus for Continuous Measurement of Active Uptake of Radioactive Substances}

\section{ECKEARD LOOS}

\section{Fachbereich Biologie der Universitat, Universiatasstr. 31} D-S400 Regensburg, Germany

Received August 4,197

To obtain kiretics for the active uptake of substances into cells, tho most cornmonly employed method is to take sumples, at various times, of the cells or of the surrounding medium and to determine the content of the repeetive compound. The separation of the cells from the medium is achieved either by centrifugation or by filtration through mombrane fiters. In order to have a convenient and more direct way to follow active uptake and also effux, an apparatus bascd on the following minciple has been developed: With a membrane, the cells are kept near a radioativity-sensing device, c.g. a scintillation erystal in conjurction with a photomutiplicr. Above this is a larger volume of liquid contwing the labeled compound that is taken up. Of the total radioastirity in the medium only a small fraction is dotcited, as most of the radiation is relatively far from the crystal and is absorbed by the water. As the labeled compound is taken up by the cells, the radioactivity is concentrated on the scintillation crystal and ean be registered. The medium above the membrane has to be stirred in order to minimize concentration gradients developing during the uptake process.

\section{DESCRIPTION OF THE APPARATUS}

The cells are confmed in a round flat compartment. Its bottom is a scirtillator (stilbene) over which an aluminized polyester foil $(6 \mu \mathrm{m})$ is stretched by use of on 0 -ring to prevent contamination (Fig. 1). The scintillator is cemented to a supporting Plexiglas base. The hejgit of the compartment is $0.1 \mathrm{~mm}$, determined by a ring-shaped polyethylene spacer, and the top is formod by a Sartorius nitroccllulose rnembrane filter, pore widh $3 \mu \mathrm{m}$. The filter is drawn with an O-ring over one ond of a Plexiglas cyinder the inner diameter of which matches that of the spacer. To apply ceils to the apparatus, a small drop of suspension is set on the coatcl scintillator; the spacer is put on the membrane filter

(C) 1972 by Academic Pross, Inc.

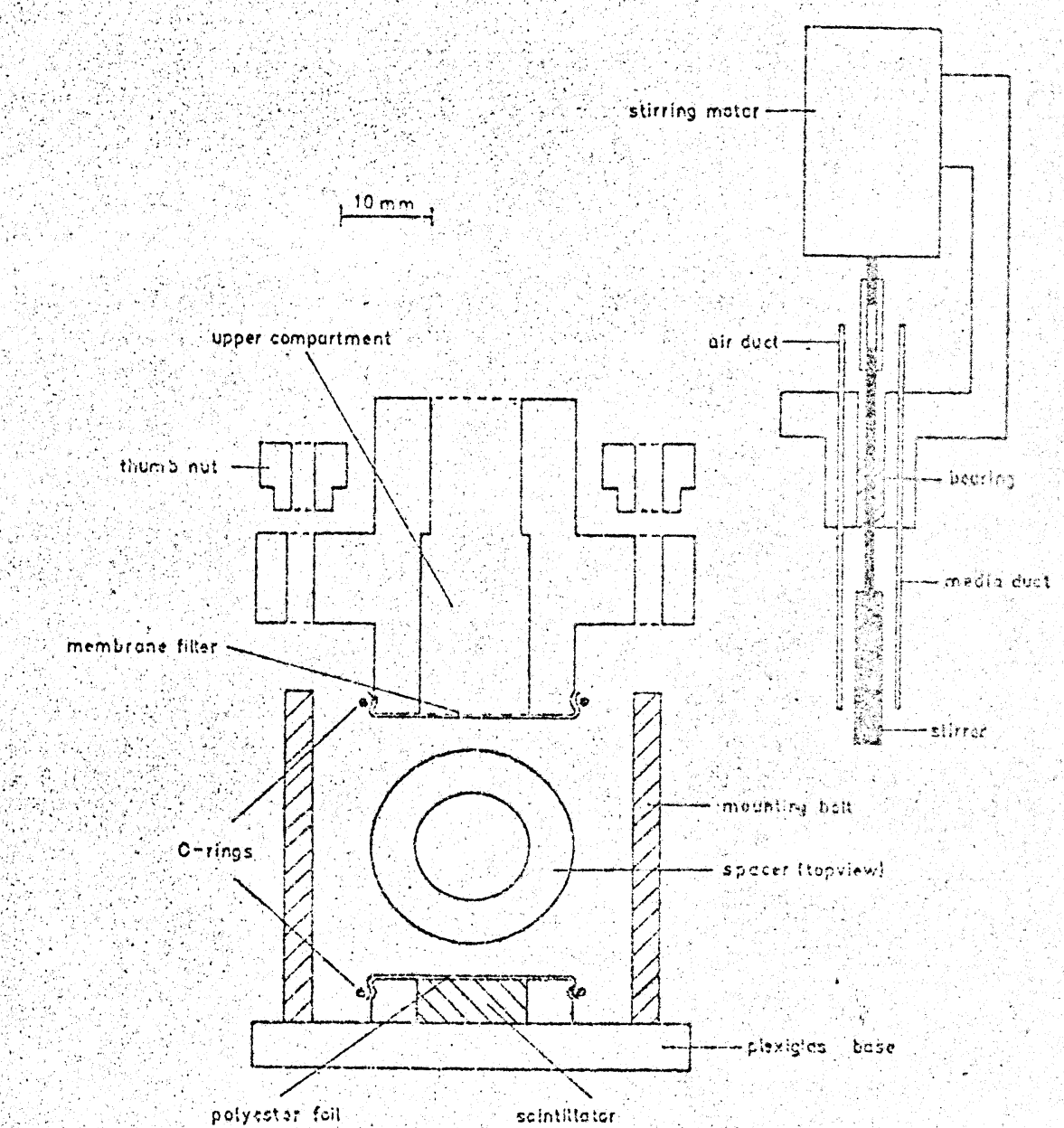

Fra. 1. Eetun for measuring liptake of mdioative stbstances by colls. Fent bu pillg-in unit (top right) not shown for clurity.

(aircady mounted to the Plexighs cylinder), adlering to it becouse it is moist, Since the middle part of the cylindor wil is sinped as a motruding ring, with holes that fit comesponding bolts from the ploxigles basc, it is centered and screwed down with thunb nuts, hay execes coll suspension is thes equeezed out. In the top of tha cyinder a unit with a moto-diven stiror, a vent, and two stainless-stel thes in feed in gases and lichuids is phoged in. The whole assombly is phen on tho

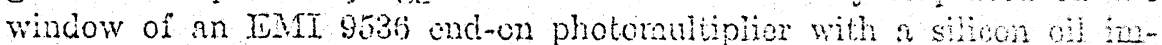
mersion beween the windorr and the Plexighes base and is set weder a light-iight eover. Liquids can be added or withdrawn through 0.5 mm 
1.d. black plastic tubing with a syringe outside the cover. The photo multiplier is connected to a Fricseke FH 49 counter, which provides an outle to record the level of radioactivity.

\section{APPLICATIONS}

For the method outlined to be useful, it is essential that the rate of diffusion through the membrane filter does not limit the rate of uptake by the cells. Therefore first experiments werc carricd out without cells to discover the linetics of mere diffusion.

Diffusion experiments. Into the space above the membrane filtcr (upper space or compartment) was pipetted $0.2 \mathrm{ml} 0.08 \mathrm{M}$ sodium phosphate buffer, pH 6.5. The space bencath the membrane filter (lower space or compartment) was also filled with buffer; its volume was only 11 fl Then $1 \mathrm{ml}$ of solution with ${ }^{14} \mathrm{C}$-labeled $\mathrm{D}$-glucose or a $\mathrm{D}$-glucose analog containing $1-2 \mu \mathrm{Ci}$ was injected into the upper compartinent and the increase in radioactivity registered. Figure 2 shows an cxample of the kineties obtained in this way. After about $2-3$ min the radioactive substance had equilibrated between the two compartments. The measured radionctivity was proportional to the concentration of radionctivity in the medium; in the equilibrated state $1140 \mathrm{cpm}$ corresponded to 1 $\mu \mathrm{Ci} / \mathrm{ml}$.

Rate constants were calculated from the maxinum change in radioactivity after injection and from the final amplitude. A series of five experiments with $\alpha$-inethyl-D-glucoside gave an averege value of $1.1 \%$ $10^{-2} \mathrm{sec}^{-1}$, the maximum deviations being $+25 \%$ and $-20 \%$. Similar values were obtained with $3-O$-methyl-D-glucose and $p$-glucose. The rate constant was used to estimate the maximum diffusion rate for later,

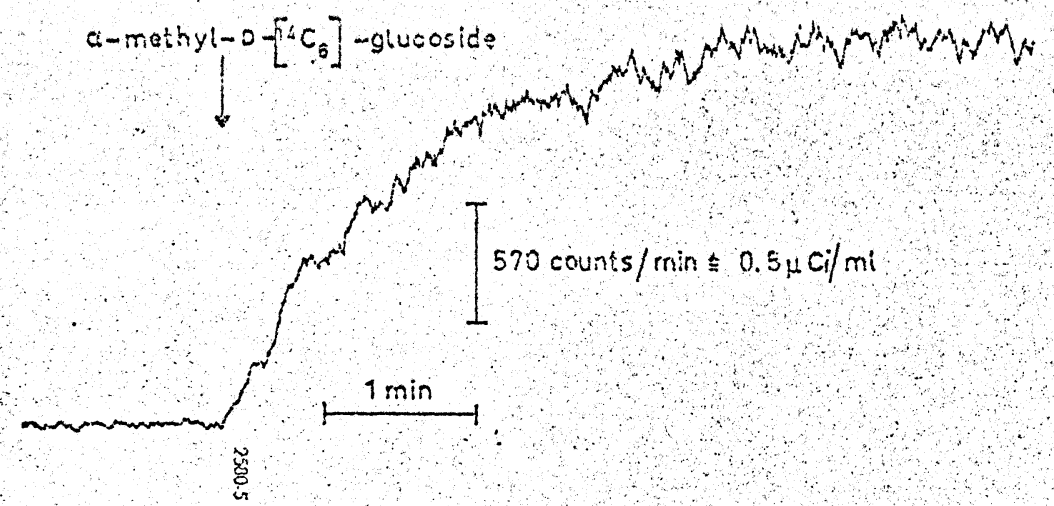

Fuc 2 . Tocrense in mensued radinactivity with time on fudition of a-methyl-is* $\left[{ }^{14} \mathrm{C}_{6}\right]$-glucoside. To cells present. cxporiments with colls, whene the low lovel of radionetivity usca obliteratcd a lirect mersurement of the difinion rate.

By faster stirring with a propeller-shaped stirrer it was possible to obtain rate constants up to $2 \times 10^{-2} \mathrm{sec}^{-1}$. Probably this condition makes possible a compicte mixing in the upper compartment almost immediately, whereas with low-speed stirring and a rectangular stirrer (Fig. 1) \& zone of less turbulence forms somewhat above the membrane fiter. This may lead to a longer equilibration time in the upper compartinent itself and, by inference, also between the two compartments. The rapid stiming was not employed further, as with algae in the lower compartment pressure changes or turbulences transduced through the nombrane filter calsed the cells to distribute unevenly.

3-O-Methyl-1-glucose uptake by Chlorella vilguris. Unichluar agre, c.g., Chlorella, are able actively to take up sugar analogs that have accumulated more than 100 -fold without heing further metabolived $(1,2)$. For the experiments reported here, Chlorella was grown as doscribed previously (3). Since the uptake system for D-glucose and $D-\mathrm{cli}_{\mathrm{i}}$ cose analogs in Chlorclla vulgaris is inducible (1-3), the cells (40 ul packed cells $/ \mathrm{ml}$ suspension) were preincubated with $7 \times 10^{-3} \mathrm{M}$ b-gincose for 2-3 hr, after which time all v-glucose had been takon up and matabolized (1).

All cxpcriments wore carried out in $0.08 \mathrm{M}$ sodium phosphate bufior, pH 6.5 ; the upper compartment was aerated to prevent oxy gen deplotion in the algal layer. Because of the manifold accumulation of the lubel in the cells, a much smaller amount of radioactivity could be omployed $(0.1 \mu \mathrm{Ci})$ than was used in the diffusion expcriments.

Irinetics. Figure 3 a hlows an eximple of uptake and effux kinctica of 3-O-methyl-D-glicosc. The increase in mensured radionotivity to be cxpected upon equilibration in the absence of alge is indicated by the dotted lines. The dashod line shows the corresponding inital rate of cliffusion calculated with the rate constrint montioner sbove.

The efflux of 3-0-methyl-D-glucose out of the algae was made apparent. by adding a small volume of nonlabeled D-glucose solution. This sort of emix (countertransport) with Chlorella was found previonily (a). Surprisingly, effux ratos could bo scveral-fold higher than the calculated maximum difusion ante. Obviously, as soon as tho laboled substance is cxtruded from the layer of algae in aimost inmediate contact with the scintillotor, it is no longer detected ever without having passed throuth the mombrne fiiter into the upper space.

This explanation has been substantiated by detemining the aboutivity of thin layers of water for ${ }^{2} \mathrm{C}-\beta$-racliatiou. In this case the upra. comparment of the apparatus was closed with a 3.5 wn think polyostor 


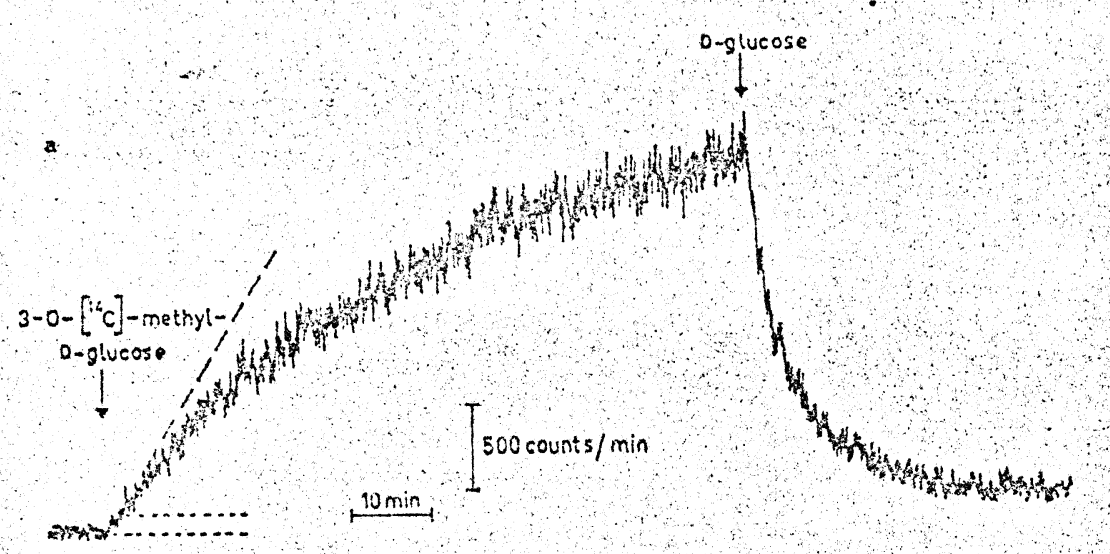

TABIS 1

Absorption of ${ }^{14} \mathrm{C}-\beta$-Radiation by Layers of Water of Different Thickncsses

\begin{tabular}{|c|c|}
\hline $\begin{array}{l}\text { Thickness of water } \\
\text { (spacer) } \\
\text { mm }\end{array}$ & $\begin{array}{l}\text { Measured radioactivity, } \\
\text { To of maximum }\end{array}$ \\
\hline $\begin{array}{l}0.10^{a} \\
0.05 \\
0.025 \\
0.0\end{array}$ & $\begin{array}{r}0 \\
7 \\
18 \\
100\end{array}$ \\
\hline
\end{tabular}

a Spacer hormally used in the exporiments described.

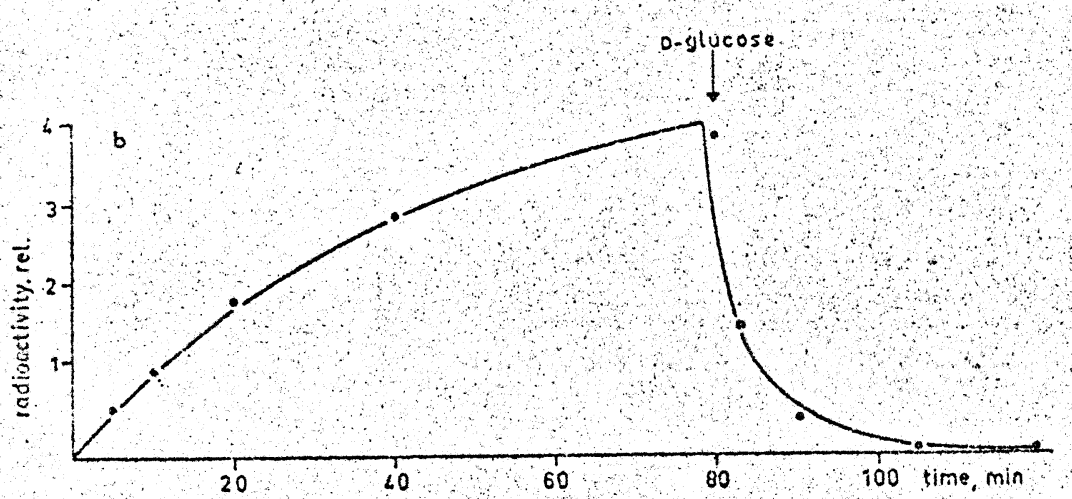

FIg. 3. (a) Uptake and effux of $3-0-\left[{ }^{11} \mathrm{C}\right]-$ methyl- - -glucose with Chlorclla vulgaris. Initial couccitration $6.25 \times 10^{-6} \mathrm{M}$ corresponding to $0.1 \mu \mathrm{Ci} / \mathrm{mil}$; increase in radionctivity to be scen without nlgae is indicated by dolted lines, the calculoied mainum diffusion rate by the dashed line. A suspension with 70 al packed cellsiml ras applied to the lower compartment; liquid volume in upper space $1.0 \mathrm{ml}$. Entux was initiated by adding $0.05 \mathrm{ml} 0.25 \mathrm{M}$-n-glucose solution. (b) Kinetics of $3-0-\left[{ }^{2} \mathrm{C}\right]$-metinyl-D-glucose uptake and emux obtained with the membrane filter technigue (points) and with our apparatus (full ijne, talien from Fig. 3a).

foil impervious to water and filled with a solution of labeled $a-$ methyl-Dslucoside $(1-2 \mu \mathrm{Ci} / \mathrm{ml})$. Between this radiation source and the scintillator differcnt amounts of water were brought with the help of spacers of various thicknesses. It became evident (Table 1) that about $30 \%$ of the $\beta$-radiation wos absorbed by a layex of water only 25 , wh thick. Therefore the high emux rates may reflect a quick upward diflusion of the labeled substance into a space 25 um and more above the scintillator yet under the membrane filter.

The actual uptake (effux) kinetics one may assume to show up about
2 min after injection of 3-O-methyl-1-glucose (D-giucose), this tine bcing nocessary for the substances to diffuse to the algas. This is depictod in Fig. 30 (full line), where only the part beginning 2 anin after injection has been redrawn from the trace in Fig. $3 a$.

Comparison with another method. To check the validity of the resutes obtained with our apparatus, comparisons were made with a standard method for measuring uptake processes. With the standard method, 0 nl of algal anspension (2-3 pl packed cells/ml) was shaken in th Erlenmeyer flask in the presence of labeled 3-0-metinyl-p-gltcose $(0,13$ ${ } \mathrm{Ci})$ of the same concentration as used in the opparatus. Airgute wete withdrawn at intorvals and the cells cxtracted after membranc ntwation as described previously (4). The radioactivity of the extract was cetermined in a liquid scintillation counter.

A parallel experiment of the kinetics of Fig. $3 \mathrm{a}$ (respecively, $3 \mathrm{~b}$, full line) was performed with alga of the same baten wing the comptional fiter tochnique. The rentit is shown by the points in Fig. 5 , which satisfactorily fit the curve obtained with the new rethod. Noto that the arow indicating addition of glucose refers to the experiment with the standard method. In the curre fiom the apparatus, glucose was scled 2 min carlier; howerer, offux then staris wh only 0.5 min delay, probably bccatse it is already fully initiated after minule amouts of glucose have reached the algae.

In further experiments, the $K_{\text {, }}$ for the uptake of $3-0-m e t h y-1-g h c o s o$ was detcrmined with both technigus, olways using the samo aigul meparations. With the new mothod, intial uplake rates wero oblained from the tangents through the points 3 min after injection of $3-0$-methy D-glucose (compare Tig. 40). With the standaw techirne, the 2.5 min values were used. A typical rosilt is shown in Mig. 4. Both methods gare a $K_{m}$ of about $6 \times 10^{-4} \mathrm{M}$

Calibration. In view of the fair argecrnent with the slandard technique 

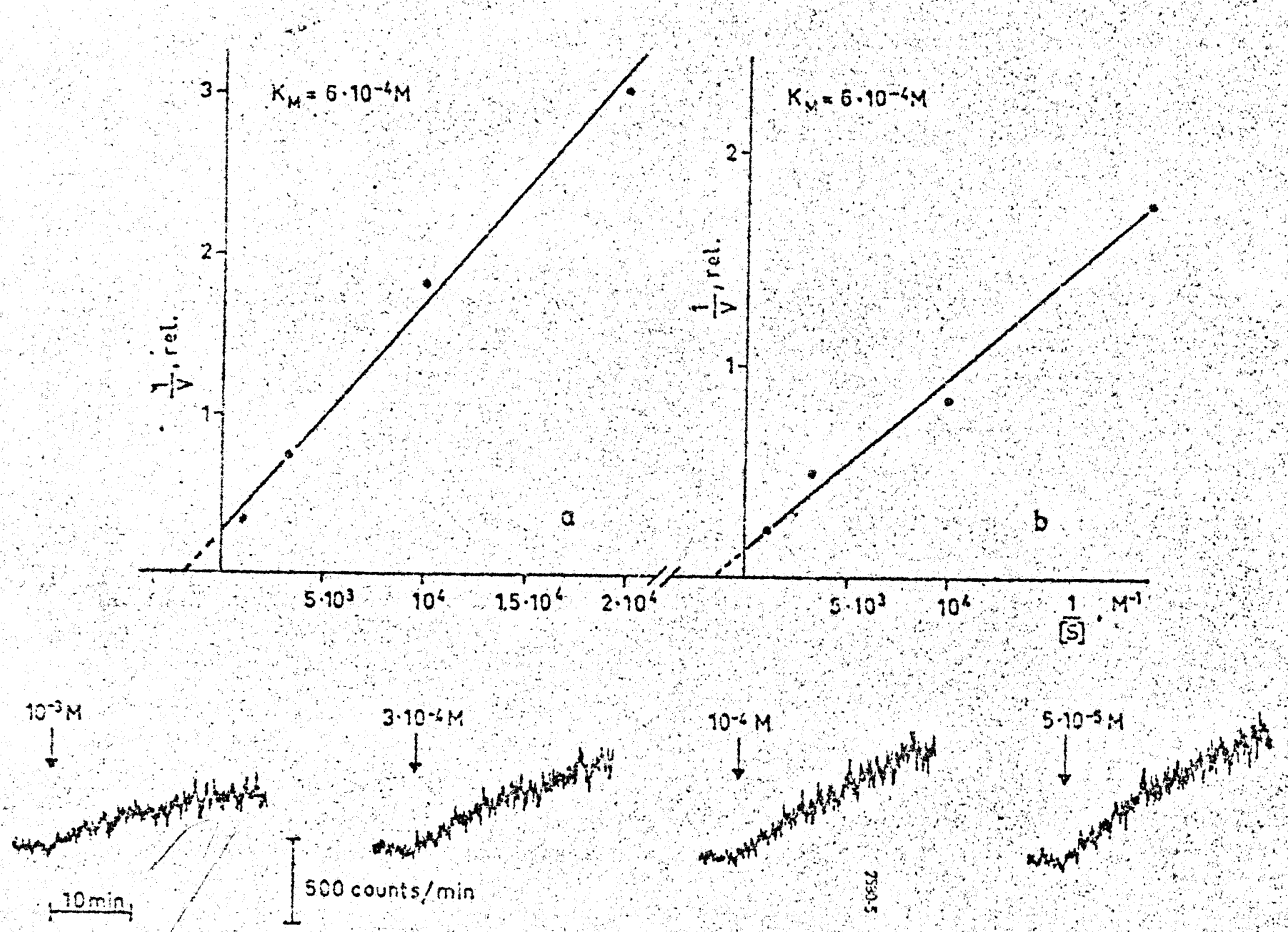

Fro. 4. (a) Lincweaver-Burk plot of uptate ates (V) for $3-0$-methyl-D-glucose obtained from kinetics shown in Fig. 4c. (b) Yinnweaver-Burk plot of uptake rates (2.5 min values) obtained with standard membranc filter technique. (c) Original traces produced with the apparatus. Arrows indicate injection of $3-0-\left[{ }^{14} \mathrm{C}\right]$-methyl-Dglucose solution containing $0.1 \mu \mathrm{Ci}$ in all cases; a suspension with $50 \mu 1$ jacked colls/ml wra anplied to the lower compartment.

an attempt was made to calibrate the rolative uptake rates obtaincd with our apparatus. For that pupose the cell density in the lower compartinent wos kept to about 50 , l packed cella/ml and tho increaso in radioactivity (counts/min ${ }^{2}$ ) was measured for the interval between 3 and 8 min after injection of labeled 3-O-mothyl-n-glucose. These rates, represcuting about the first 5 min of uptake by the algte, were further corrected, assuming a standard specifo activity of $1.0 \mathrm{Ci} / \mathrm{mole}$ had been employed. Comparison was then made with the rates measured for the first $5 \mathrm{~min}$ in parailel experiments using the standard technique. As an average from eight exporiments inyolving five bateics of higue an lutale rate of I mole/hr.ml packed cells was found to corrcspond to an increase in radioactivity of $3.44 \mathrm{counts} / \mathrm{min}^{2}$, the maximun doviations being $+47 \%$ and $-26 \%$. From that relation one con derive:
This cxpression can be used to estamate from the additional wadionotity in the presence of algae the molnitity of 3-0-mony-D-glueose inside the cells (assuming the 3-O-methyl-p-ghucose is unformly distributed in the cell). Fnowing the 3-O-methyl-n-glucose concentration in the medium, one can further estimate the ratio 3-0-methyl-p-gucose concentration inside futside the coll. For instance, in the oxpenment shom

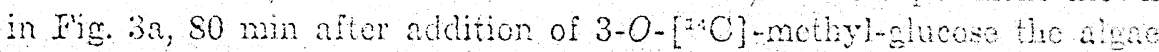
gave $2140 \mathrm{cpm}$; the specifc activity wo $16 \mathrm{Ci} / \mathrm{mol}$-therefore wh $1 \mathrm{Ci}$ mole (the specific activity for which the calbration is yalid) one would have observed $134 \mathrm{cpm}$. With the expresion given above one calonIates the concentration of 3-O-methy-p-ciucose misic the colls as

$$
134 / 2.00^{-} \times 10^{5}=0.0 \times 10^{-4} \mathrm{H}
$$

The initial outside concentration of $3-0$-methyl-D-glueose was $0.25 \times$ $10^{-6} \mathrm{M}$ in a total volume of $1 \mathrm{ml}$. This concentration had changed aumg the uptake process: The lower compatment contancd approximatepy $0.75 \mathrm{~m}$ packed cells, which ater 80 min had reachod a $3-0$-methyglucose concentration of $6.5 \times 10^{-4} M r$; the ontside concchtration then must have corre to

$$
6.25 \times 10^{-6}-6.5 \times 10^{-4} \times 0.75 / 1000=5.77 \times 10^{-3} \mathrm{M}
$$

The ratio inside/cutside concentration is, then, $6.5 \times 10^{-4} / 5.77 \times 10^{-14}$ $=113$.

In addition, a different approach was made to calibrate the systow. $A s$ is known from experinerts without algae (compare Fig. 2), a shit in measured radioactivity of $1140 \mathrm{cpm}$ is generated by a change in $14 \mathrm{C}$ concentration of $1 / \mathrm{Ci} / \mathrm{ml}$ in the medium; having a specific activity of 1 $\mathrm{Ci} /$ mole, a change by $1 \mu \mathrm{Ci} / \mathrm{ml}$ corresponds furthor to a concentration change of $10^{-3} M$. When one observes in the presence of algae an increase in radionctivity of $1140 \mathrm{cpm}$ (specifo activity agnin $1 \mathrm{C} / \mathrm{mole}$ ), the concentration inside the algae has increased by $10^{-3} \mathrm{~W}$ also if tho following conditions are fulfilled:

(a) above the scintillator the space whose radioactivity is regtsteres is completely fillod with algao;

(b) the aigae do not change the counting ofreiency.

The first condition probably is net met and one can reason as follows: If the algae occupy oniy an effective fraction $f$ of the snace whose radionctivity is monitored, then a wolarity change of $10^{-2} M$ in the algao would yield only a change by $f \times 1140 \mathrm{~cm}$ (specifo activity agan 1 $\mathrm{Ci} /$ mole). A molarity change in the cells of $1 M=1$, wole/ $M$ packed cells would colrespond to $f \times 1.14 \times 10^{\circ} \mathrm{cpm}$ 
We tried to detcrmine $f$ in the following way: $\Lambda$ labcled compound that camot penctrate algat cells is brought into the medium. If no algac are present, the measurel radioactivity has a certain level; with algne in the lorier compartment, less radioactivity will be secn, as the cellsimpervious to the labeled compound-sort of dilute the radionctivity. The fraction by which the algae diminish the original radioastivity level should then bo cqual to the cffective fraction $f$ which tho algae occupy from the relevant apace above the scintillator.

A suitable substance that docs not enter Chlorella cells is $\alpha$-methyl-Dglucosicie. This has been shorv experimentally: To $2 \mathrm{ml}$ of a thick Chlorella suspension with 300 il packed cells $/ \mathrm{ml}$ (value corrected for intercellular water according to (5)), $0.05 \mathrm{ml} \alpha$-methyl-D- $\left[{ }^{14} \mathrm{C}_{6}\right]$-glucoside solution was added. After 5,15 , and 50 min, samples were withdrawn and contrifuged, and aliquots of the supernatant checked for their radioactivity. In the control, instead of algal suspension, the same volume of bufier was mixed with the $\alpha$-methyl-D-glucosicle solution. After 5 and

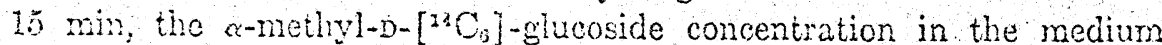
of the Criloralla suspension was found to be 1.43 times as high as in the control, as would be expected if no $\alpha$-methyl-D- $\left[{ }^{14} \mathrm{C}_{9}\right]$-glucoside had penetrated the cells. After $90 \mathrm{~min}$, the concentrations differed still by a factor 1.24 .

Figure o shows which fraction $f$ of the radioactivity due to $\alpha$-methyl $D-\left[{ }^{14} \mathrm{C}_{0}\right]$-giveoside is screened off with different coll concentrations in the lower compatment. It is evident that even thicls suspensions do not completely occupy the space detectable by the scintillator. Further, it can

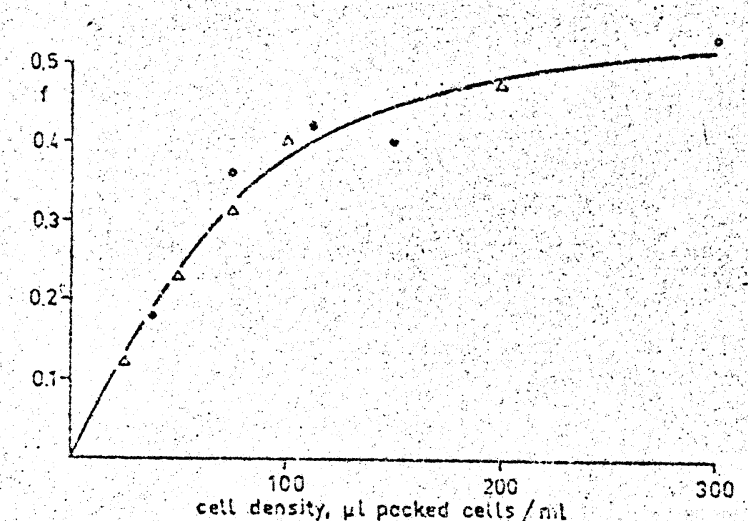

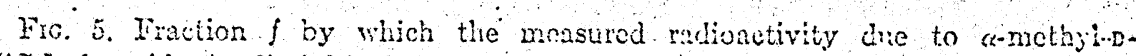
["Co]-glucoside is dininished in dependence on cell tensity in ile lowen compartnent. Triangies and points belcrgg to experiments with different algal meparations. be scen from Tig. ot that cell concentrations of a certain percentage couse an cron higher perentage of weakening of radioactivity, e.g., with a suspension of $50 \mathrm{kl}$ packed cells/m $(=5 \%)$ a weakoning of already $23 \%$ is achieved. This may be explained by a settling of the colls, so that the cells are more densely packed in the lajer the radionetivity of which is detected by the scintillator.

Taking $f=0.23$ for $50 \mu$ packed colls $/ \mathrm{ml}$, our calibration comes out with 1 mole/ $\mu$ packed cells $=0.23 \times 1.14 \times 10^{3}=2.62 \times 10^{5} \mathrm{~cm}$. From comparison with the membrane filter technique, an actuil concontration change by 1 umole/ $\mu$ packed cells was found to yold the somewhat smaller radioactivity change of $2.06 \times 10^{5} \mathrm{cmm}$. This suggests tho rndioactivity in the colls is colnted los efrochtly than that bo the
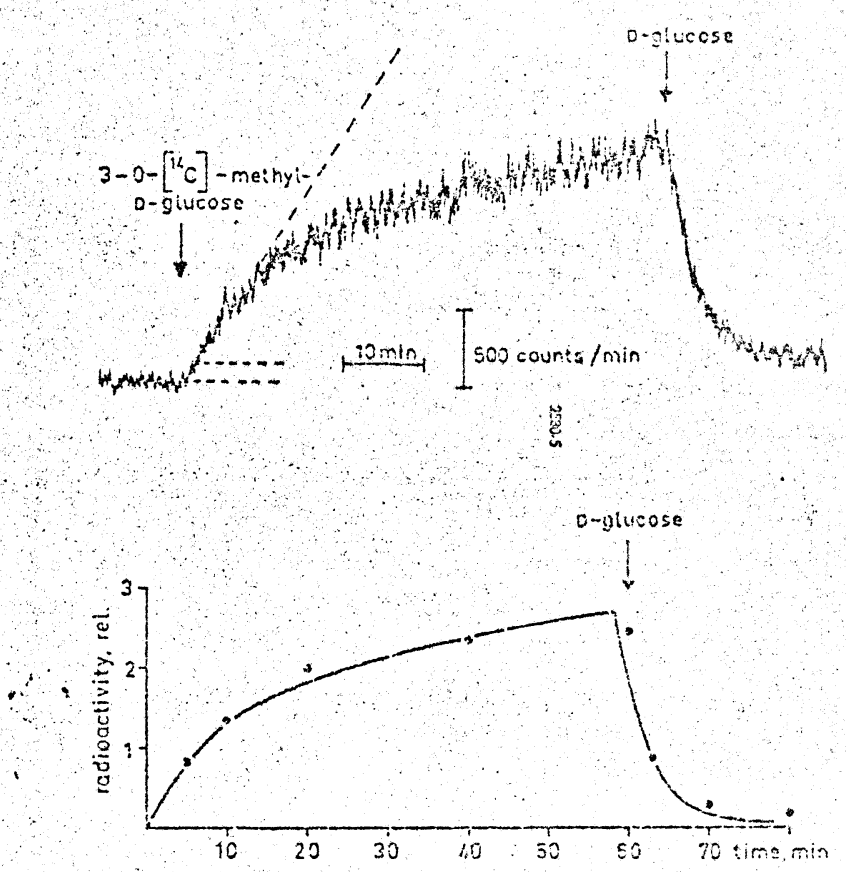

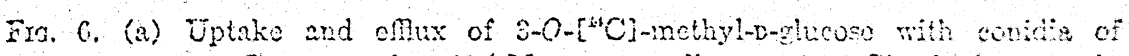
Neurospora crass. Cozentrelion $10^{-4}$ in corresponding to $0.1 \mu \mathrm{CD} / \mathrm{ml}$; incrato in redionctivity to be secn willout conidia is indiezted by dotted lines, the colcu-

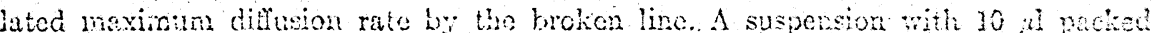

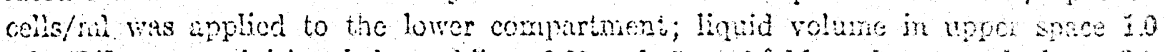

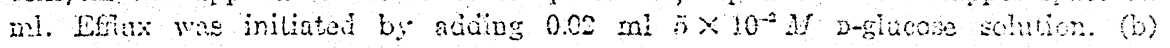

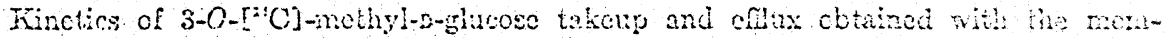
brane after technique (points) and with the spparatus (full lina, tutho from Fig. 6a). 
outside medium. This might be due to an uneven distribution of the label in the cell and/or a stronger absorption of $\beta$-radiation by the cell wall than by water.

S-O-Methyl-D-glucose uptake by Neurospora. Neurospora conidia can accunulate 3-O-methyl-D-glucose in the cell manifold above the concentration in the modium, furthermore, a countertransport has becn fond to occur on acidition of glicose (6). These processes secmed promising for further testing of the applicability of the apparatus.

Nontrospora crassa strain 74-OR 23-1A De Serres was grown as described chewhere (7); condia wore harvested in Fries minimal modium (8) and for the experiments transfered into $0.03 \mathrm{~W}$ sodium phosphate buffer, $\mathrm{p}, \mathrm{H}$ 6.5. An original trace of the linetics ootained is depicted in Fig. 6a. Comparison was also made with the membrane filter technique. Cell concentration was, in these experiments, approximately $0.8 \mu \mathrm{l}$ packed cells/ml; otherwise the procedure was the same as with Chlorella. As showa in Fig. 6 b, both methods gave about the same kinetics.

\section{DISCUSSION}

When comparing the inerits of the two methods used in this work for uptake moasurement, the nombrane filter technique seems better suited for short-tern kinctics, e.g., uptake during the first 2 min after addition of substratc. If, however, one is concened with uptake phonomena traing place in a time range of $10 \mathrm{~min}$ or longer, the new nothod seems to bo competitive; it also is more time-saving.

Comparison with snother method should always be made when working with a ney organism. It has been tried, for instance, to reasure $\alpha$-methyl-D-glucoside uptake with Salmonella typhimurium, but only qualitative agreement of the kinctics has been found as compared with the filter technique, although accumulation of radionctivity could bc clearly demonstrated with the apparatus.

Yimprovenents in the response time of the apparatus might be achicved with membrane filters allowing faster diffusion between the two comparments. One could even omit the mombrane filter if thin thalli or flamentous algae were held to the scintillator only at its circumference.

\section{SUMMARY}

An apparatus is described allowing the registration of uptake kinetics of radionctire compounds by celis. Cells are held in a thin leyer close to a scintillation crystal so that uptake of a laboled compound is seen as an increase in measured radioactivity. As a demonstration of the method, accumulation and countertransport kinetics are shown with $3-O-\left[{ }^{11} \mathrm{C}\right]$-methy]-D-glucose for Chlorella vulgaris and for conidia of
Neurospora crassa for Chorelio a $\mathrm{K}_{m}$ of $6 \times 10^{-4} M$ is found for the uptake. Farallel experiments with the membrane filter technicuc show good agrecmont and can be wised to calibrate the apparatus.

\section{ACKNOWLEDGMENS}

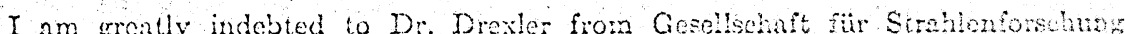
For the we of the photomuliplior and the scintillation cystal, ard to D: Tauner for his stimuln ing interest, Dr. YNlingmüler for providing conidia of Nethuspara, and Miss:H. Meyer for skillful technical assistance.

\section{RETERENCES}

1. Tansm, W., Biochem, Biophys. Res. Commun. 38, 278 (nno9).

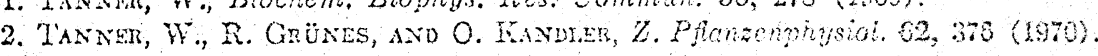

3. TaNver, W, aNi O. Kandiar, Z. Pfutenzenphisioi. 5 S, 21 (1067).

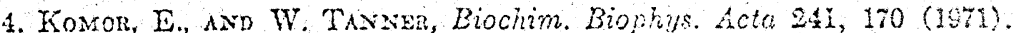

5. Barrer, J., Biockim. Biophys. Acta 150, 61 (196S).

6. Scarmorocum, G. A., J. Biol. Cham. 245, 7, 1094 (1070).

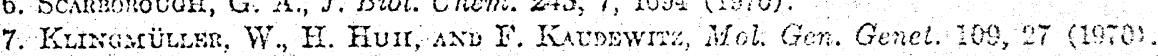
8. Bender, G. W., and T. L. Tatuas, Amer. J. Bot 32, Gis (1015). 